\title{
The prevalence of ovine Sarcocystis species in Izmir province*
}

\author{
Aysen BEYAZIT ${ }^{1}$, Öznur YAZICIOĞLU ${ }^{2}$, Zafer KARAER ${ }^{3}$ \\ ${ }^{1}$ Parasitology Laboratory, Bornova Veterinary Control and Research Institute, Izmir; ${ }^{2}$ Pathology Laboratory, Bornova Veterinary \\ Control and Research Institute, Izmir; ${ }^{3}$ Department of Parasitology, Faculty of Veterinary Medicine, Ankara University, Ankara.
}

\begin{abstract}
Summary: This study was carried out to determine the prevalence of ovine Sarcocystis species in Izmir province. A total of 734 muscle samples of 200 sheep from four different age groups were surveyed by the digestion and histological examination methods for the presence of Sarcocystis species. Sarcocystis ovifelis, Sarcocystis ovicanis, and Sarcocystis arieticanis were detected as the responsible species for ovine sarcosporidiosis in Izmir province. Macrocysts of S.ovifelis were found in 24.5\% (49/200) of sheep and the highest prevalence was detected in the oesophagus in all age groups. Microcysts of S.ovicanis and S.arieticanis were present in $86.5 \%(173 / 200)$ of sheep. The prevalence of Sarcocystis cysts increased significantly with the age. Although microcysts were detected in $46 \%(23 / 50)$ of lambs up to 6 months of age, they were present in all muscle samples of sheep (150/150) over 6 months of age. Histologically, no inflammatory reaction was seen against sarcocysts within the infected muscles, unless they degenerated. There was no significant difference $(\mathrm{p}>0.05)$ statistically between sensitivities of two diagnostic methods (digestion and histology) in detecting Sarcocystis species. These results reveal the fact that the environment is heavily contaminated with sporocysts, and the ingestion of sporocysts by sheep begins from the young ages in Izmir province.
\end{abstract}

Key words: Izmir, prevalence, Sarcocystis spp, sheep.

\section{İzmir İl'inde koyun Sarcocystis türlerinin yayılıșı*}

Özet: Bu çalışma, İzmir ilinde koyun Sarcocystis türlerinin yayılışını belirlemek amacıyla yapıldı. Bu amaçla dört farklı yaş grubundan 200 koyuna ait toplam 734 kas örneği, Sarcocystis türlerinin varlı̆̆1 yönünden enzim tekniği ve histolojik muayene metodları ile araştırıldı. İzmir ilindeki koyunlarda sarcosporidiosis'den sorumlu türler, S.ovifelis, S.ovicanis ve S.arieticanis olarak tespit edildi. S.ovifelis makrokistleri, koyunların \% 24,5 (49/200)'inde bulundu ve tüm yaş grublarında en yüksek prevalans ösefagusta tespit edildi. S.ovicanis ve S.arieticanis mikrokistleri, koyunların \% 86,5 (173/200)'inde mevcuttu. Sarcocystis kistlerinin prevalansı, yaş ile önemli derecede arttı. Mikrokistler, 6 aylığa kadar olan kuzuların \% 46 (23/50)'sında bulunduğu halde, 6 aylıktan büyük koyunların tüm kas örneklerinde mevcuttu. Histolojik olarak, kistler dejenere olmadıkça, enfekte kas tellerindeki sarkokistlere karşı yangısal bir reaksiyon görülmedi. Sarcocystis türlerinin tespitinde, iki teşhis metodunun (enzim tekniği ve histoloji) duyarlılıkları arasında istatistiksel olarak önemli bir fark $(\mathrm{p}>0,05)$ bulunmadı. Bu sonuçlar, İzmir ilinde çevrenin sporokistler ile yoğun şekilde kontamine olduğu ve koyunlar tarafından sporokist alımının genç yaşlardan itibaren başladığı gerçeğini ortaya koymaktadir.

Anahtar sözcükler: İzmir, koyun, prevalans, Sarcocystis spp.

\section{Introduction}

Sarcocystis is one of the most prevalent protozoan parasites in the striated muscles of livestock slaughtered for food such as cattle, sheep and goat. Four species of Sarcocystis have so far been identified from domestic sheep. Of these, S.ovicanis (synonymous $=$ S.tenella) and $S$. arieticanis, pathogenic species, form microscopic cysts and are transmitted via canids, the definitive hosts, whereas $S$. ovifelis (synonymous $=S$. gigantea) and $S$. medusiformis, non-pathogenic species, form macroscopic cysts and are transmitted via felids (5). Many reports (4, $6,13,22,23)$ on the prevalence of ovine Sarcocystis species have revealed that sarcosporidiosis is still an extremely common infection even in the most developed countries of the world. The prevalences of ovine Sarcocystis species detected in different provinces of Turkey have also ranged from $55 \%$ to $100 \%(16,21,26$, 28, 29).

The main objective of the study reported here was to determine the prevalence of ovine Sarcocystis species in Izmir province by using the digestion and histological examination methods. In addition, the pathological lesions observed in the muscles with sarcocysts, and the influence of age and sex on the prevalence of Sarcocystis species were also investigated.

\footnotetext{
* This study was supported by TAGEM, Ministry of Agricultural and Rural Affairs (Project no.TAGEM/HS/98/10/04/034).
} 


\section{Materials and Methods}

Muscle samples were collected between October 1998 and October 2000 from 200 sheep both slaughtered at various abattoirs in Izmir province and necropsied in Bornova Veterinary Control and Research Institute under 6 months of age for the purpose of diagnosis. All sheep had been raised in different locations of Izmir province. A total of 734 muscle samples from the oesaphagus, diaphragm, and heart of all sheep and also from the tongue and skeletal muscles (gluteus medius) in some of them were examined for the presence of Sarcocystis species by the digestion and histological techniques. Sheep were surveyed in four groups according to their ages: up to 6 months, over 6 months to 1 year, over 1 year to 2 years, and over 2 years. The muscle samples from a total of 50 sheep for each age group were taken. They were initially examined by the naked eye for the presence of macrocysts. The found cysts were counted and measured for their dimensions. Later, the samples were divided into two sets: one set for digestion procedures, the other set for histological examinations. For the digestion, ten grams of each muscle sample were homogenized in a blender and digested in a $\mathrm{NaCl}$ buffered $0.25 \%$ trypsin solution, as described by Erber (7). After a 10 to $15 \mathrm{~min}$ incubation at $20^{\circ}-25^{\circ} \mathrm{C}$, the digest was sieved through a nylon-meshed tea strainer and centrifuged within the tubes with conic bottom at $1500 \mathrm{rpm}$ for $10 \mathrm{~min}$ (Hettich Universal 16). After discarding the supernatant fluid, one to two drops from the sediment at the bottom were examined microscopically for Sarcocystis microcysts.

For histological examinations, the muscle samples with or without macrocysts were fixed in $10 \%$ neutral buffered formalin during the necropsy or within the latest two hours after slaughter, prepared the paraffin blocks, sectioned at 4 to 5 micron, stained with haematoxylin and eosin (H\&E), and examined microscopically for sarcocysts. Selected tissue sections with macrocysts were also stained with periodic acid Schiff (PAS). The wall morphologies of sarcocysts in the muscle sections were examined under oil immersion.

Sarcocystis species present in the muscle samples were identified on the basis of the differences in the wall morphologies of sarcocysts, as described by Dubey et al. (5). The shortest and longest dimensions of each sarcocyst were also recorded. Both the sensitivities of two diagnostic methods (digestion and histology) and the differences in prevalences of microcysts according to the muscles of different organs and sex in sheep from four different age groups were evaluated statistically by using the $\mathrm{z}$ test (9). Values of $\mathrm{p}<0.001$ were considered significant.

\section{Results}

Sarcocystis macrocysts were found in 49 (24.5\%) of 200 sheep. The highest prevalence of macrocysts was detected in sheep over 2 years old and in the oesophagus in all age groups (Table 1).

Table 1. The prevalence of sarcocystis macrocysts in the muscles of different organs in 49 sheep with macrocysts from four different age groups.

Tablo1. Dört farkl1 yaș grubundan makrokistli 49 koyunda farklı organ kaslarında sarcocystis makrokistlerinin prevalansı.

\begin{tabular}{lccccc}
\hline & \multicolumn{3}{c}{ Numbers of sheep with macrocysts } \\
\multirow{2}{*}{$\begin{array}{l}\text { Examined } \\
\text { organ muscles }\end{array}$} & \multicolumn{3}{c}{ Age groups } & $\begin{array}{c}\text { Total } \\
\text { number } \\
(\%)\end{array}$ \\
\cline { 2 - 5 } & 1.group 2.group 3.group & 4.group & \\
\hline $\mathrm{O}$ & 1 & 2 & 14 & 15 & $32(16)$ \\
$\mathrm{T}$ & - & - & 1 & 2 & $3(1.5)$ \\
$\mathrm{H}$ & - & - & 1 & 2 & $3(1.5)$ \\
$\mathrm{O}+\mathrm{T}$ & - & - & 1 & 3 & $4(2)$ \\
$\mathrm{O}+\mathrm{D}$ & - & - & 2 & 3 & $5(2.5)$ \\
$\mathrm{O}+\mathrm{D}+\mathrm{T}$ & - & - & - & 1 & $1(0.5)$ \\
$\mathrm{O}+\mathrm{D}+\mathrm{T}+\mathrm{H}$ & - & - & - & 1 & $1(0.5)$ \\
Total number $(\%)$ & $1(2)$ & $2(4)$ & $19(38)$ & $27(54)$ & $49(24.5)$ \\
\hline
\end{tabular}

$\mathrm{O}$ : Oesophagus; $\mathrm{T}$ : Tongue; $\mathrm{H}$ : Heart; D : Diaphragm

1.group: up to 6 months; 2.group: $>6$ months to 1 year; 3.group: $>1$ year to 2 years; 4 .group: $>2$ years

Diaphragmatic macrocysts were spindle-shaped and elongated, and measured 8-14 x 3-6.5 mm, whereas those found in the oesophagus, tongue, and heart muscles were round-oval shaped, and measured 0.25-12 x 0.25-8 mm. In histological sections, macrocysts had the morphological features corresponding to the description of $S$. ovifelis. They were thin walled, surrounded by a secondary thick cyst wall which is stained positively with PAS (Figure 1). There was no evidence of any degeneration or inflammatory reaction in the muscle fibers surrounding macrocysts.

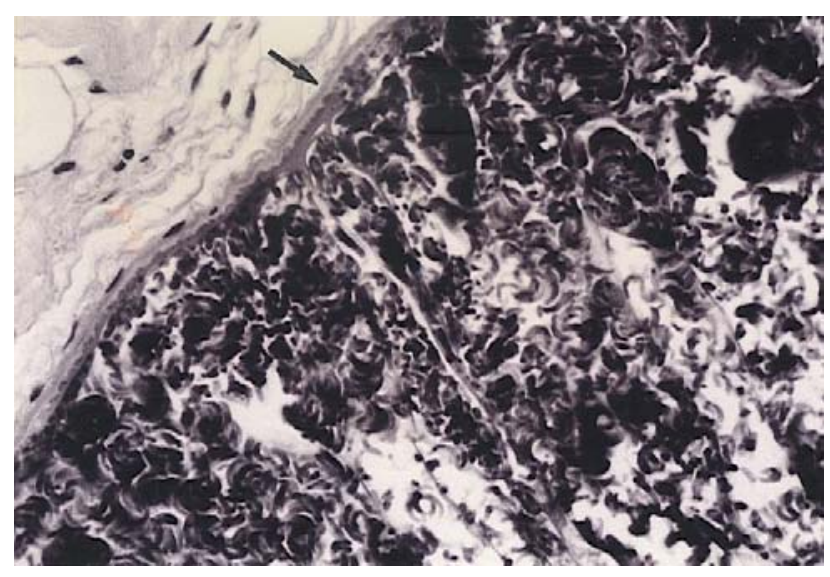

Figure 1. Sarcocystis ovifelis macrocyst in oesophagus. Secondary thick cyst wall (arrow). periodic acid Schiff x 400 . Şekil 1. Özefagusta Sarcocystis ovifelis makrokisti. Sekonder kalın kist duvarı (ok). periodic acid Schiff x 400. 
Table 2. The prevalence of sarcocystis microcysts determined by the digestion method and histological examination in the muscles of different organs in 200 sheep from four different age groups.

Tablo 2. Dört farklı yaş grubundan 200 koyunun farklı organ kaslarında enzim tekniği ve histolojik muayene metodları ile tespit edilen sarcocystis mikrokistlerinin prevalans1.

\begin{tabular}{|c|c|c|c|c|c|c|c|c|c|c|}
\hline \multirow{3}{*}{$\begin{array}{l}\text { Age } \\
\text { groups }\end{array}$} & \multicolumn{10}{|c|}{ Examined organ muscles } \\
\hline & \multicolumn{2}{|c|}{ Oesophagus } & \multicolumn{2}{|c|}{ Diaphragm } & \multicolumn{2}{|c|}{ Heart } & \multicolumn{2}{|c|}{ Tongue } & \multicolumn{2}{|c|}{ Skeletal muscles } \\
\hline & $\mathrm{D}$ & $\mathrm{H}$ & $\mathrm{D}$ & $\mathrm{H}$ & $\mathrm{D}$ & $\mathrm{H}$ & $\mathrm{D}$ & $\mathrm{H}$ & $\mathrm{D}$ & $\mathrm{H}$ \\
\hline $\begin{array}{l}\text { 1.group } \\
(\%)\end{array}$ & $\begin{array}{c}23 / 50^{*} \\
(46)\end{array}$ & $\begin{array}{c}23 / 50 * \\
(46)\end{array}$ & $\begin{array}{c}23 / 50 \\
(46)\end{array}$ & $\begin{array}{c}22 / 50 \\
(44)\end{array}$ & $\begin{array}{c}22 / 50 \\
(44)\end{array}$ & $\begin{array}{c}23 / 50 \\
(46)\end{array}$ & $\begin{array}{c}7 / 31 \\
(22.6)\end{array}$ & $\begin{array}{c}7 / 31 \\
(22.6)\end{array}$ & $\begin{array}{l}1 / 25 \\
(4)\end{array}$ & $\begin{array}{c}2 / 25 \\
(8)\end{array}$ \\
\hline $\begin{array}{l}\text { 2.group } \\
(\%)\end{array}$ & $\begin{array}{l}50 / 50 \\
(100)\end{array}$ & $\begin{array}{l}50 / 50 \\
(100)\end{array}$ & $\begin{array}{l}50 / 50 \\
(100)\end{array}$ & $\begin{array}{l}50 / 50 \\
(100)\end{array}$ & $\begin{array}{l}50 / 50 \\
(100)\end{array}$ & $\begin{array}{l}50 / 50 \\
(100)\end{array}$ & $\begin{array}{l}15 / 15 \\
(100)\end{array}$ & $\begin{array}{l}15 / 15 \\
(100)\end{array}$ & $\begin{array}{c}3 / 3 \\
(100)\end{array}$ & $\begin{array}{c}3 / 3 \\
(100)\end{array}$ \\
\hline $\begin{array}{l}\text { 3.group } \\
(\%)\end{array}$ & $\begin{array}{l}50 / 50 \\
(100)\end{array}$ & $\begin{array}{l}50 / 50 \\
(100)\end{array}$ & $\begin{array}{l}50 / 50 \\
(100)\end{array}$ & $\begin{array}{l}50 / 50 \\
(100)\end{array}$ & $\begin{array}{l}50 / 50 \\
(100)\end{array}$ & $\begin{array}{l}50 / 50 \\
(100)\end{array}$ & $\begin{array}{l}15 / 15 \\
(100)\end{array}$ & $\begin{array}{l}15 / 15 \\
(100)\end{array}$ & $\begin{array}{c}2 / 2 \\
(100)\end{array}$ & $\begin{array}{c}2 / 2 \\
(100)\end{array}$ \\
\hline $\begin{array}{l}\text { 4.group } \\
(\%)\end{array}$ & $\begin{array}{l}50 / 50 \\
(100)\end{array}$ & $\begin{array}{l}50 / 50 \\
(100)\end{array}$ & $\begin{array}{c}49 / 50 \\
(98)\end{array}$ & $\begin{array}{l}50 / 50 \\
(100)\end{array}$ & $\begin{array}{l}50 / 50 \\
(100)\end{array}$ & $\begin{array}{l}50 / 50 \\
(100)\end{array}$ & $\begin{array}{l}37 / 38 \\
(97.4)\end{array}$ & $\begin{array}{l}38 / 38 \\
(100)\end{array}$ & $\begin{array}{c}5 / 5 \\
(100)\end{array}$ & $\begin{array}{c}5 / 5 \\
(100)\end{array}$ \\
\hline $\begin{array}{l}\text { Total } \\
(\%)\end{array}$ & $\begin{array}{l}173 / 200 \\
(86.5)\end{array}$ & $\begin{array}{c}173 / 200 \\
(86.5)\end{array}$ & $\begin{array}{c}172 / 200 \\
(86)\end{array}$ & $\begin{array}{c}172 / 200 \\
(86)\end{array}$ & $\begin{array}{c}172 / 200 \\
(86)\end{array}$ & $\begin{array}{c}173 / 200 \\
(86.5)\end{array}$ & $\begin{array}{l}74 / 99 \\
(74.5)\end{array}$ & $\begin{array}{l}75 / 99 \\
(75.6)\end{array}$ & $\begin{array}{l}11 / 35 \\
(31.4)\end{array}$ & $\begin{array}{l}12 / 35 \\
(34.3)\end{array}$ \\
\hline
\end{tabular}

$\mathrm{D}=$ Digestion method; $\mathrm{H}=$ Histological examination;

* $\mathrm{x} / \mathrm{n}=$ The number of infected animal/The number of examined animal.

1.group: up to 6 months; 2.group: $>6$ months to 1 year; 3.group: $>1$ year to 2 years; 4 .group: $>2$ years

The overall prevalence of Sarcocystis microcysts in all sheep with or without macrocysts was detected as $86.5 \%$ (173 of 200) (Table 2). No significant difference $(p>0.05)$ was statistically found between sensitivities of two diagnostic methods in detecting Sarcocystis species in all age groups. In histological sections, microcysts were observed from 2.5 months of age, and immature

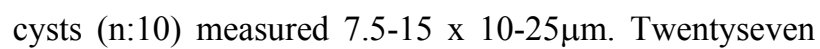
sheep (54\%) aged up to 6 months had no microcyst (Table 2). Sarcocystis microcysts were present in all muscle samples of sheep over 6 months of age (Table 2). The prevalence of microcysts according to the sex was shown in Table 3.

Table 3. The prevalence of sarcocystis microcysts according to the sex in 200 sheep from four different age groups.

Tablo 3. Dört farklı yaş grubundan 200 koyunda cinsiyete göre sarcocystis mikrokistlerinin prevalans1.

\begin{tabular}{lccccccccc}
\hline \multicolumn{1}{c}{ Age groups } \\
Sex & $\begin{array}{c}1 . \\
\text { group }\end{array}$ & $\%$ & group & $\%$ & group & $\%$ & group & $\%$ \\
\hline Female & $18 / 35$ & 51.4 & $19 / 19$ & 100 & $39 / 39$ & 100 & $46 / 46$ & 100 \\
Male & $5 / 15$ & 33.3 & $31 / 31$ & 100 & $11 / 11$ & 100 & $4 / 4$ & 100 \\
Total & $23 / 50^{*}$ & 46 & $50 / 50$ & 100 & $50 / 50$ & 100 & $50 / 50$ & 100
\end{tabular}

$* \mathrm{x} / \mathrm{n}=$ The number of infected animal/The number of examined animal.

1.group: up to 6 months; 2.group: $>6$ months to 1 year; 3.group: $>1$ year to 2 years; 4 .group: $>2$ years
Two types of microcysts were differentiated on the basis of their cyst wall morphologies. Sarcocysts, thinwalled with hair like projections, were identified as S.arieticanis, and sarcocysts, thick-walled with radial striations, as S.ovicanis (Figure 2). Of 173 sheep with microcysts, 63 (31.5\%) were only infected by S.ovicanis and $110(55 \%)$ had mixed infection. Whereas the numbers of S.arieticanis cysts in muscle samples in 95 $(86.3 \%)$ of 110 sheep with mixed infection were usually limited to a few sarcocysts, their numbers in the remainder $(13.7 \%)$ were more than or very close to those of S.ovicanis cysts.

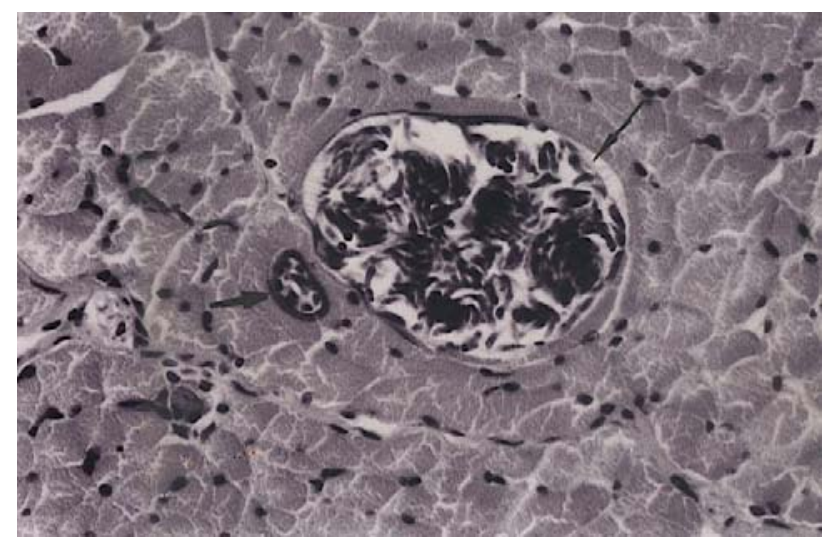

Figure 2. Sarcocystis ovicanis (thick arrow), thick-walled with radial striations, and Sarcocystis arieticanis (thin arrow), thinwalled with hair like projections, in the tongue. Haematoxylin and eosin $\mathrm{x} 400$.

Şekil 2. Dilde radyal çizgili kalın duvarlı Sarcocystis ovicanis (kalın ok) ve saç benzeri uzantılara sahip ince duvarlı Sarcocystis arieticanis (ince ok) mikrokisti. H\&E x 400. 
Histologically, microscopic cysts from immature cysts with metrocytes to mature cysts with bradyzoites were observed in varying intensity in muscle sections. In the heart muscles, sarcocysts were also seen in Purkinje fibres as well as in the muscle fibres of the myocardium. In all muscle samples examined, most of the muscle fibres containing seemingly intact sarcocysts showed usually no evidence of any pathological change or inflammatory reaction. However, there were intense mononuclear cell infiltrations with variable numbers of neutrophil leucocytes within and around the degenerated sarcocysts. In some of the muscle fibres with such degenerative cysts, sarcoplasm had also lost its striations and become amorphous. Most of the muscles with sarcocysts had focal to multifocal, mild interstitial mononuclear cell infiltrations, largely surrounding the vessels and rarely separating the muscle fibres, without associated with the intensity of sarcocysts. These cell infiltrations very rarely surrounded the muscle fibres with sarcocysts. Multifocal mild mononuclear cell infiltrations were also present in the subepicardial tissue of the hearts.

\section{Discussion and Conclusion}

Sarcocystis ovifelis, a macroscopic sarcocyst the most often identified from sheep, is of a worldwide distribution (1, 2, 4, 6, 13), whereas $S$. medusiformis, another ovine macrocyst, has so far been reported only from several countries $(1,3,17)$. In Turkey, the prevalence rates of macrocysts in sheep have ranged from $6.1 \%$ to $66 \%$ in abattoir surveys performed in different provinces $(8,16,26,28,29)$. In the present study, S.ovifelis sarcocysts were found in $24.5 \%$ (49 of $200)$ of sheep. The highest prevalence $(16 \%)$ recorded in the oesophagus was similar to the observations of other some researchers $(2,11-13)$, except for that of Ozturk and Kucukerden (20) who detected the highest prevalence of cysts in the diaphragm. Macrocysts have been reported to be found mostly in adult sheep $(1,2,26$, 27, 29). In this study, the prevalence of S.ovifelis macrocysts increased with age and was significantly higher in sheep over 2 years old than in the younger sheep (Table 1). S.ovifelis was found in 3 sheep under 1 year old, supporting the finding of Svobodova and Nevole (27) who reported macrocysts in a young sheep. This finding suggests that macrocysts may develop in a time less than 1 year, unlike the previous observation that they need at least one year to develop (15).

Microscopic ovine Sarcocystis species have been observed to be more prevalent than macroscopic cystforming species in Turkey $(14,16,21,26,29)$ and other many countries $(1,2,4,6,13)$. The overall prevalence of microcysts in 200 sheep surveyed in four different age group in the present study was also higher than that recorded for macrocysts. The differences in prevalence between the age groups were significant $(p<0.001)$ in sheep aged up to 6 months. Microcysts were found in 23 (46\%) lambs in this age group. While the prevalences of microcysts in the oesophagus, heart, and diaphragm were similar, the lowest prevalences were respectively in the skeletal muscles and tongue (Table 2). The prevalences of microcysts recorded in lambs in different countries have been reported as $22.6 \%$ in those under 6 months of age in Austria (6), $58.33 \%$ in those under 3 months of age and $79.05 \%$ in those between 3 and 12 months of age in Spain (13), $35.67 \%$ in Czechoslovakia (27), and $18.3 \%$ in the United States $(25)$. In some studies $(20,29)$ performed in Turkey, the prevalences of Sarcocystis microcysts have ranged from $34 \%$ to $100 \%$ in sheep under 1 year old. In this study, the prevalence of microcysts also significantly increased with age, as indicated by findings of the previous many studies $(1,6$, 13, 20, 27). All sheep over 6 months of age had microcysts (Table 2).

The observations of some studies performed on ovine sarcosporidiosis have shown that no significant difference was found in prevalence between both sex of sheep $(13,25)$. While the prevalence of Sarcocystis species recorded in this study was higher in females than males of sheep aged up to 6 months $(p<0.001)$, the prevalence was $100 \%$ in all female and male sheep over 6 months of age (Table 3). Therefore, it seems that the prevalence of microcysts increasing with age was not associated with sex.

The results of many surveys $(10,22-24,26)$ on ovine Sarcocystis species have revealed that sheep are infected by either only one or both Sarcocystis species forming microcysts in the muscles, as in the present study. None of sheep was infected by only S.arieticanis, unlike the findings of some studies in Turkey $(20,26$, 29 ). Additionally, the number of S.arieticanis microcysts present in the muscle samples in most of the mixed infections was also limited to a few sarcocysts, similar to the observations of Dubey et al. (4).

It has been reported that sarcocysts within the muscle fibres had usually no associated host reaction but some toxic substances may be released, causing a strong immune response, when they were ruptured (5). In experimentally infected lambs, O'Toole et al. (19) have also observed that an associated host response to cysts occurred largely within the infected muscle fibres, when sarcocysts degenerated. In his another study, O'Toole (18) has ultrastructurally detected that a mild or moderate myositis developed during both meront and cyst-forming 
stages, and only a small proportion of muscle fibres with cysts attracted a local inflammatory reaction, consisting of macrophages and plasma cells. In this study, it was seen neither any degenerative change and necrosis within the infected muscle fibres, unless sarcocysts degenerated, nor haemorrhages even in the muscle samples with numerous cysts, in contrast to the observations of some studies $(17,20)$.

Various diagnostic methods are used for the detection of sarcosporidiosis $(1,4,10,11,13)$. We used the digestion and histological examination methods and compared these two diagnostic methods. Both diagnostic methods had similar sensitivities $(p>0.05)$, like the findings of Savini et al. (23) who compared the same methods in sheep. However, the high prevalence of ovine Sarcocystis species in Izmir province may have increased the our chance of detecting sarcocysts in the examined muscles.

The results of the present study have revealed that the prevalence of pathogenic ovine Sarcocystis species in Izmir province was $46 \%$ in those less than 6 months of age, and $100 \%$ in those over 6 months of age. In addition, these results points out the reality that the environment is heavily contaminated with sporocysts, and the ingestion of sporocysts by sheep begins from the young ages. Therefore, it has of great importance the farmers to be trained not to feed their dogs and cats with uncooked meat, and the abattoir remnants to be burned, in order to be effectively broken of infection cycle between the intermediate and the definitive hosts in Izmir province.

\section{Acknowledgements}

The authors thank the veterinarians and other personnel of Municipality abattoirs in Izmir province for their help and cooperation in supplying the muscle samples.

\section{References}

1. Abo-Shehada MN (1996): Age variations in the prevalence of sarcocystosis in sheep and goats from northern and central Jordan. Prev Vet Med, 27, 135-140.

2. Britt DP, Baker JR (1990): Causes of death and illness in the native sheep of North Ronaldsay, Orkney. I. Adult sheep. Brit Vet J, 146, 129-142.

3. Collins GH, Atkinson E, Charleston WAG (1979): Studies on sarcocystis species. III. The macrocystic species of sheep. N Z Vet J, 27, 204-206.

4. Dubey JP, Lindsay DS, Speer CA, Fayer R, Livingston CW (1988): Sarcocystis arieticanis and other Sarcocystis species in sheep in the United States. J Parasitol, 74, 10331038.

5. Dubey JP, Speer CA, Fayer R (1989): Sarcocystosis of Animals and Man. CRC Press Inc, Boca Raton, Florida.
6. Egger A (1994): Sarkosporidien beim Schlachtschaf in Osttirol. Wien Tierarztl Mschr, 81, 247.

7. Erber M (1977): Möglichkeiten des Nachweisses und der Differenzierung von Zwei Sarcocystis-Arten des Schweines. Berl Münch Tierarztl Wochenschr, 90, 480-482.

8. Göksu K (1975): Koyunlarda sarcocystosis'in yayılışı üzerinde araştırmalar. İstanbul Üniv Vet Fak Derg, 1, 110-127.

9. Kesici T, Kocabaş Z (1998): Biyoistatistik. Ankara Üniversitesi Basımevi, Ankara Üniv Eczacılık Fak Yay No. 79.

10. Kudi AC, Aganga AO, Ogbogu VC, Umoh JU (1991): Prevalence of sarcocystis species in sheep and goats in Northern Nigeria. Rev Elev Med Vet Pays Trop, 44, 59-60.

11. Latif BMA, Al-Delemi JK, Mohammed BS, Al-Bayati, SM, Al-Amiry AM (1999): Prevalence of Sarcocystis spp. in meat-producing animals in Iraq. Vet Parasitol, 84, 85-90.

12. Mal'a P, Baranova, M (1995): Diagnosis of sarcocystis infection in slaughtered animals at veterinary meat inspection. Vet Med-Czech, 40, 97-100.

13. Martinez-Moreno A, Moreno-Montanez T, MartinezGomez F, Hernandez-Rodriguez S, Martinez-Cruz S (1989): Prevalence of ovine sarcocystosis in Cordoba, Spain. Rev Iber Parasitol, 49, 283-285.

14. Maskar U, Özder M, Dikmen S (1971): Çeşitli kasaplık hayvan türleri ile et müstahzaratlarında sarkosporidi bakımından histolojik araştırma. Mikrobiol Derg, 24, 86104.

15. Munday BL (1978): Cats as definitive hosts for sarcocystis of sheep. N Z Vet J, 26, 166.

16. Okur H, Kandemir O, Şahin İ (1995): An investigation on sarcocystis species in the cattle and the sheep in Bayburt. T Parazitol Derg, 19, 113-118.

17. Oryan A, Moghaddar N, Gaur SNS (1996): The distribution pattern of sarcocystis species, their transmission and pathogenesis in sheep in Fars Province of Iran. Vet Res Commun, 20, 243-253.

18. O'Toole D (1987): Experimental ovine sarcocystosis: sequential ultrastructural pathology in skeletal muscle. J Comp Pathol, 97, 51-60.

19. O'Toole D, Duffell SJ, Upcott DH, Frewin D (1986): Experimental microcyst sarcocystis infection in lambs: pathology. Vet Rec, 119, 525-531.

20. Öztürk G, Küçükerden N (1996): Elazığ Et ve Balık Kurumu mezbahasinda kesilen koyunlarda sarcocystis türlerinin yayılışı. Etlik Vet Mikrob Derg, 8, 74-83.

21. Reztlaff N (1972): Über das Vorkommen von Sarkosporidien bei schlachtschafen und schlachtziegender Türkei. Schlacht Viehhof Ztg, 72, 192-196.

22. Saito M, Shibata Y, Itagaki H (1996): Sarcocystis arieticanis of sheep in Japan (Protozoa:Apicomplexa). Jpn J Parasitol, 45, 290-294.

23. Savini G, Dunsmore JD, Robertson ID, Seneviratna $\mathbf{P}$ (1993): Sarcocystis spp in Western Australian sheep. Aust Vet J, 70, 152-154.

24. Schmidtova D, Jurasek V (1992): Seasonal dynamics of the excretion of sarcocystis sporocysts in the faeces of dogs in relation to the incidence of sarcocystosis in sheep. Veterinastvi, 42, 48-49. 
25. Seneviratna P, Edward AG, DeGiusti DL (1975): Frequency of Sarcocystis spp. Detroit, Metropolitan area, Michigan. Am J Vet Res, 36, 337-339.

26. Sevinç F, Altınöz F, Uslu U, Aldemir OS (2000): Koyunlarda sarcocystis türlerinin yaygınlığı. Vet Bil Derg, 16, 75-79.

27. Svobodova V, Nevole M (1990): Use of the muscle digestion method and indirect immunofluorescence reaction in the diagnosis of sarcocystosis in sheep. Acta Vet Brno, 59, 157-170.

28. Taşçı S, Değer S (1989): Van mezbahasında kesilen koyunlarda sarcocystosis'in yayılışı. Ankara Üniv Vet Fak Derg, 36, 540-552.

29. Tüzer E, Demir S (1987): Bursa yöresinde koyunlarda sarkosporidiozis. İstanbul Üniv Vet Fak Derg, 13, 12-20.
Gelis tarihi: 03.05.2006 / Kabul tarihi: 21.09.2006

\author{
Address for correspondance \\ Dr. Öznur Yazıcıŏglu \\ Bornova Veteriner Kontrol ve Araştırma Enstitüsü \\ Müdürlüğü, \\ Patoloji Laboratuvarl, \\ 35010 İzmir \\ e-mail: oznurya@yahoo.com
}

